\title{
The sequential binge: a new therapeutic approach for binge eating
}

\author{
Remi Neveu ${ }^{1}$, Guillaume Barbalat ${ }^{2 *}$, Dorine Neveu ${ }^{3}$, Giorgio Coricelli ${ }^{4}$, Ulrike Schmidt ${ }^{5}$, Alain Nicolas ${ }^{6}$ \\ From 2015 ANZAED Conference: Riding the Waves to Recovery \\ Surfers Paradise, Australia. 21-22 August 2015
}

\section{Introduction}

A significant proportion of eating disorder patients experiencing binge eating do not respond to cognitive behavioral therapies (CBT). Here, we present a new behavioral technique, the sequential binge (SB) that aims at reducing both food intake during binges and daily binge numbers. Specifically, SB replaces the usual pattern of food ingestion during a binge by a repeated monotonous food ingestion sequence interspersed with short incremental pauses. This pattern of ingestion is hypothesised to facilitate boredom towards the ingested foods and promote a sense of control over binge foods.

\section{Methods}

15 eating disorder in-patients with refractory binge eating who were non-responsive to intensive CBT were given SB as an adjunct to their treatment. Patients were followed up for 16 weeks after SB implementation.

\section{Results}

Compared to regular binges, SB was associated with a $44 \%$ relative reduction in the planned food intake during binges $(p<0.001)$, a longer refractory period after the binge (median: $48 \mathrm{hrs}$ vs. $4 \mathrm{hrs}, \mathrm{p}=0.002$ ), and an average relative reduction of binges by $26 \%$ the day after SB $(\mathrm{p}=0.004)$.

\section{Conclusion}

This case series shows promising evidence for the use of $\mathrm{SB}$ in patients with refractory binge eating. Further evaluation of the use of SB for refractory binge eating in a prospective double-blind clinical study seems justified.

\footnotetext{
* Correspondence: guillaumebarbalat@gmail.com

${ }^{2}$ Regional Eating Disorders Service, Greenlane Clinical Centre, Auckland, New Zealand

Full list of author information is available at the end of the article
}

\begin{abstract}
Authors' details
${ }^{1}$ Université de Lyon, Neuroscience Research Center, Lyon, France. ${ }^{2}$ Regional Eating Disorders Service, Greenlane Clinical Centre, Auckland, New Zealand. ${ }^{3}$ Université Montpellier, Montpellier, France. ${ }^{4}$ Interdepartmental Centre for Mind/Brain Sciences (CIMeC), University of Trento, Trento, Italy. ${ }^{5}$ Section of Eating Disorders, Institute of Psychiatry, King's College, UK. ${ }^{6}$ Hôpital du Vinatier, Bron, France.
\end{abstract}

Published: 23 November 2015

doi:10.1186/2050-2974-3-S1-O57

Cite this article as: Neveu et al:: The sequential binge: a new

therapeutic approach for binge eating. Journal of Eating Disorders 20153 (Suppl 1):057.
Submit your next manuscript to BioMed Central and take full advantage of:

- Convenient online submission

- Thorough peer review

- No space constraints or color figure charges

- Immediate publication on acceptance

- Inclusion in PubMed, CAS, Scopus and Google Scholar

- Research which is freely available for redistribution

Submit your manuscript at www.biomedcentral.com/submit
C Biomed Central 